\title{
A Comparative Study of Chain Clamping Fixture with Other Clamping Methods for Gate Valve Body: Cycle Time and Rigidity Study
}

\author{
Lokeswar Patnaik, Sunil Kumar, Deva Prasad S \\ Department of Mechanical Engineering, CVR College of Engineering, Hyd-501510, INDIA
}

\begin{abstract}
Fixture rigidity influences the production rates". In this paper, a comparison and feasibility study is demonstrated to improve the productivity and existing fixture rigidity for machining on a gate valve body by comparing the existing technique i.e. top clamping fixture with other possible clamping methods including newly developed chain clamping fixture. The CAD models of the fixtures are prepared in CATIA V5. The existing fixture concept, clamping methods, cutting parameters and cycle times have been studied and compared with the values of chain clamping fixture obtained by trail out results. Along with the increased production rates, other parameters like tool life, noise and vibration levels and surface roughness values are also improved slightly.
\end{abstract}

\section{Introduction}

Gate valve body shown in Fig. 1 are machine elements which are used to control of flow of volatile, often toxic gases and liquids and keep them away from being emitted into atmosphere [1]. A gate valve body of cast steel has to undergo various machining processes and to accommodate rigidity while machining, fixtures are required. In this paper, traditional top clamping method to locate the gate valve is compared with other fixtures along with newly developed chain clamping fixture.
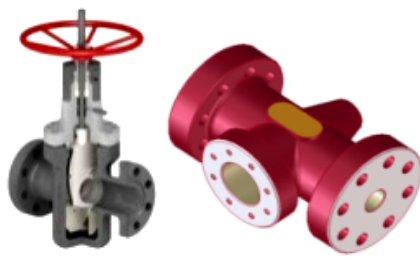

Figure 1. Valve body

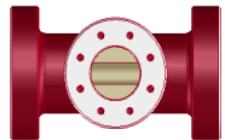

B-0 (Front view)

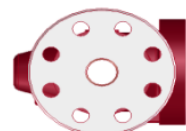

B90, B270

(Side view)

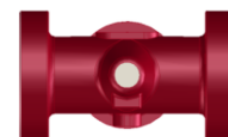

B-180

(Back view)
Figure 2. B0, B90, B270 and B180 view for OP-10 orientation.

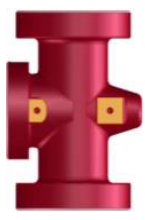

$\mathrm{B} 0$

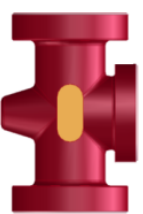

B 180
Figure 3. B0, B180 views of OP-20 orientation
Table 1. Operations wise tool requirement.

\begin{tabular}{|c|c|}
\hline Operations & \multirow[t]{2}{*}{ Tools required } \\
\hline B0 side & \\
\hline 7/8-9UNC tap & $\begin{array}{l}\text { Ø19.5 Drill and 7/8"-9 } \\
\text { UNC tap }\end{array}$ \\
\hline $\begin{array}{l}\text { Ø101.4 \& Ø 97.1 Bore } \\
\text { roughing \& Finishing }\end{array}$ & $\begin{array}{l}\text { Ø101.4 Finish Boring } \\
\text { bar }\end{array}$ \\
\hline $\begin{array}{l}\text { Face milling Rough and } \\
\text { finishing }\end{array}$ & $\begin{array}{l}\varnothing 63 \text { Face mill and } \varnothing \\
20 \text { End mill }\end{array}$ \\
\hline $3 \times 45$ degree chamfer & Chamfer Tool \\
\hline \multicolumn{2}{|l|}{ B90 \& B270 side } \\
\hline Ø25.4 Hole & Ø25.4 Drill \\
\hline Ø52.3 hole & $\begin{array}{l}\text { Ø52 Rough boring bar } \\
\varnothing 52.3 \text { Finish Boring } \\
\text { bar }\end{array}$ \\
\hline Face milling & Ø63/Ø125 Face mill \\
\hline \multicolumn{2}{|l|}{ B180 side } \\
\hline Face milling & Ø63/Ø125 Face mill \\
\hline
\end{tabular}

The majors input to fixture design consists of product design data including CAD geometric model, the machining operation sequence, the quantity to be produced and the machines on which the various operations are to be performed [2]. The machining operations are done in a horizontal machining center (HMC). The B-axis machine tool combines the turning capabilities of a horizontal/vertical turning machine with milling and machining capabilities of a five-axis machining center. A B-axis machine can do the work of two because it supports the entire range of milling and turning operations possible, with the advantage of doing it in one setup [3]. OP-10 (Operation number 10 of process sheet of the component as per the production drawing) 
and OP-20 (Operation number 20) are orientations or set up of the component (Gate valve body) in which B-0, B180 and B-270 are the views of the component in B-axis shown in Fig. 2 and Fig. 3 in which the machining have to be performed. The machining operations to be performed in operation number $10(\mathrm{OP}-10)$ along with the tools to be used are shown in Table I

\subsection{OP-10 Operational details}

\subsection{OP 20 Operational details}

In B0 side of OP-20, the operations are $2 \times 1 / 2$ "NPT Tap and spot facing whereas in B180 side face milling is the only operation.

\section{Design evolutions}

\subsection{Existing technique- Top Clamping}

Fig. 4 shows a top clamping fixture, this method employs concentrated clamping i.e clamping force will act on very small area on the component. Major drawbacks of top clamping technique are high tendency of component deformation, less rigidity than distributed load type and handling difficulties. This is popularly and widely used method but due to above mentioned demerits; its applications are limited to small components only where clamping force is significantly less. To avoid these limitations, alternative concepts were developed and evaluated.
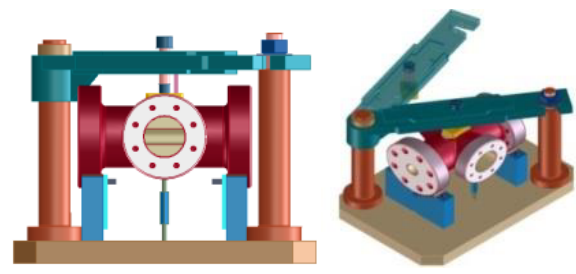

Figure 4. Top clamping fixture.

\subsection{Various concepts}

\subsubsection{Bottom Clamping}

Advantages of bottom clamping concept shown in Fig. 5 are clamping against resting thus no component deformation, high clamping forces and easy to Handle. The disadvantages of this method are high over hang portion (Unsupported flange faces) in both the operations, it limits the maximum parameters of the machine that can be used for machining.
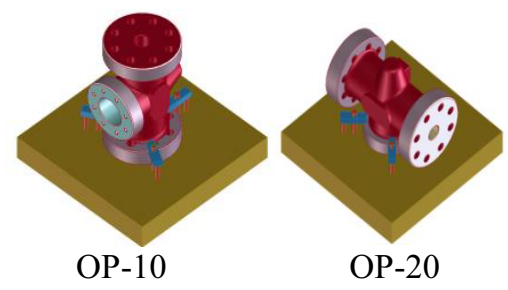

Figure 5. Bottom clamping

\subsubsection{Concept 2: Strap Clamps}

Fig. 6 shows the concept of strap clamping. In this arrangement two straps are used for clamping. The advantages of this set up are two strap Clamps against the resting $\mathrm{V}$-Blocks i.e, eliminating component deformation and provides good clamping forces. Difficulies in orientation of component and increase in loading and unloading time are the major disadvantages of this concept.

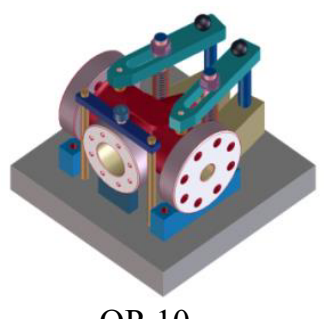

OP-10

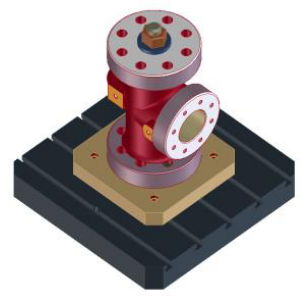

OP-20
Figure 6. Use of Two Strap Clamps

\subsubsection{Chain Clamping with orientation by studs and additional clamping}

In this concept, the component is clamped with two chain, one additional clamp and one suport pin as shown in Fig. 7. The orientation is easy, accessable and quick, also it is provided with top clamping for additional support as fall back option which is practically unnecessary as it will increase cycle time.

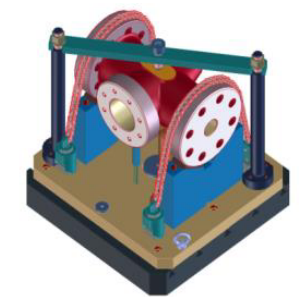

Figure 7. Chain clamping with additional clamp

\subsubsection{Chain Clamping Fixture Final Concept}

In OP-10, the component is located on v-blocks with resting and butting pads. It is orientated by two M12 Studs and clamping by two Chain Clamping Sets against resting. The clamping and orientation is shown in Fig. 8.

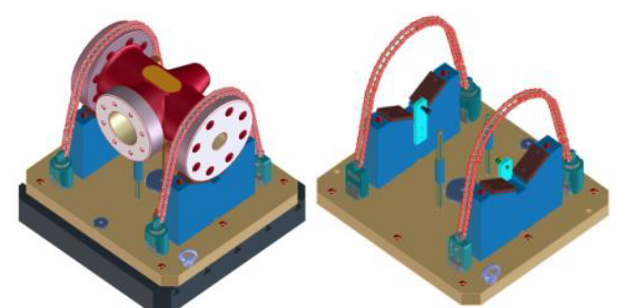

Figure 8. Chain Clamping Fixture concept OP-10

In OP-20, the component is oriented and located by two pins (Diamond pin type) diagonally which shown by color green and blue respectively. One central pin with top clamp is used for clamping the component. The fixture concept with component and without component is shown in Fig. 9. 


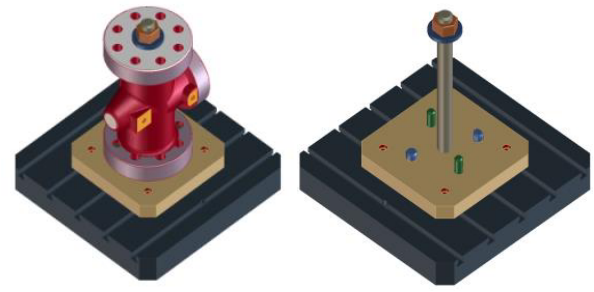

Figure 9. Chain clamping fixture concept OP-20

\section{Cycle time and cutting force calculations}

The operation wise parameters are taken from Kennametal catalogue [4] and total time taken in OP-10 and OP-20 is found out which is shown in Table 2 and Table 3 .

Table 2. OP-10 time study

\begin{tabular}{|c|c|c|c|c|c|}
\hline \multicolumn{6}{|c|}{ OP- 10 CUTTING TIME } \\
\hline SNo. & Operation & Tool & $\begin{array}{l}\text { Cycle } \\
\text { Time }\end{array}$ & RPM & Feed \\
\hline 1 & $\begin{array}{l}\text { Face } \\
\text { milling- } \\
\text { Rough }\end{array}$ & Ø63 FMC & 8.08 & 1062 & 850 \\
\hline 2 & $\begin{array}{l}\text { 7/8-9UNC } \\
\text { tapping }\end{array}$ & $\begin{array}{l}\varnothing 19.5 \\
\text { Drill }\end{array}$ & 4.00 & 978 & 97 \\
\hline 3 & & $\begin{array}{l}\varnothing 14 \mathrm{CHF} \\
\text { tool }\end{array}$ & 0.41 & 1431 & 100 \\
\hline 4 & & $\begin{array}{l}7 / 8-9 \\
\text { UNC tap }\end{array}$ & 1.47 & 200 & 430 \\
\hline 5 & Ø25.4 Hole & $\begin{array}{l}\text { Ø25.4 } \\
\text { Drill } \\
\end{array}$ & 13.06 & 778 & 77 \\
\hline 6 & Ø97.2 hole & Ø63 FMC & 5.5 & 1110 & 1644 \\
\hline 7 & $\begin{array}{l}\text { Ø101 hole - } \\
\text { Roughing }\end{array}$ & Ø63 FMC & 2.1 & 1110 & 1644 \\
\hline 8 & $\begin{array}{l}\text { Ø101 hole - } \\
\text { SF }\end{array}$ & $\varnothing 20 \mathrm{EM}$ & 0.45 & 1400 & 1200 \\
\hline 9 & $\begin{array}{l}\text { Ø101.2 hole } \\
\text { CHF }\end{array}$ & $\begin{array}{l}\varnothing 14 \mathrm{CHF} \\
\text { tool }\end{array}$ & 1.06 & 900 & 600 \\
\hline 10 & $\begin{array}{ll}\text { Ø92 } & \text { hole } \\
\text { CHF } & \\
\end{array}$ & $\begin{array}{l}\text { Ø14 CHF } \\
\text { tool }\end{array}$ & 0.50 & 900 & 600 \\
\hline 11 & $\begin{array}{l}\text { Ø101.2 } \\
\text { finish } \\
\text { boring }\end{array}$ & $\begin{array}{l}\varnothing 101.2 \\
\text { FBB }\end{array}$ & 0.35 & 314 & 31 \\
\hline 12 & $\begin{array}{l}\text { Ø52.1 hole- } \\
\text { Rough }\end{array}$ & $\begin{array}{l}\text { Ø52.1 } \\
\text { RBB }\end{array}$ & 6.02 & 616 & 61 \\
\hline 13 & $\begin{array}{l}\text { Ø52.1 hole } \\
\text { CHF }\end{array}$ & $\begin{array}{l}\varnothing 14 \mathrm{CHF} \\
\text { tool }\end{array}$ & 0.14 & 900 & 600 \\
\hline 14 & $\begin{array}{l}Ø 25.4 \text { Hole } \\
\text { CHF }\end{array}$ & $\begin{array}{l}\varnothing 14 \mathrm{CHF} \\
\text { tool }\end{array}$ & 4.02 & 900 & 600 \\
\hline 15 & $\begin{array}{ll}Ø 186 & \text { OD } \\
\text { CHF } & \end{array}$ & $\begin{array}{l}\varnothing 14 \mathrm{CHF} \\
\text { tool }\end{array}$ & 3.25 & 900 & 600 \\
\hline 16 & $\begin{array}{l}\text { Ø52.4 } \\
\text { Finish } \\
\text { Boring }\end{array}$ & $\begin{array}{l}\varnothing 52.4 \\
\text { FBB }\end{array}$ & 8.3 & 848 & 42 \\
\hline 17 & $\begin{array}{l}\text { Face } \\
\text { milling- } \\
\text { Finish } \\
\end{array}$ & $\varnothing 63 \mathrm{FMC}$ & 7.13 & 1261 & 500 \\
\hline \multicolumn{3}{|c|}{\begin{tabular}{|l} 
Total Time for OP-10 \\
\end{tabular}} & 66.23 & & \\
\hline
\end{tabular}

Cutting time for OP-10 $=66.23+10 \%$ cushion time $=$ $72.5 \mathrm{~min}$.

Non Cutting time for OP-10
Loading time $\quad=10 \mathrm{~min}$ (maximum)

Work setting time $=10 \mathrm{~min}$ (maximum)

Unloading time $=6 \mathrm{~min}$.

Total non-cutting time for OP-10 $=26 \mathrm{~min}$.

Total Cycle time for OP-10( cutting + Non-cutting $)=98.5$ $\min$.

Table 3. OP-20 time study,

\begin{tabular}{|l|l|l|l|l|l|}
\hline \multicolumn{7}{|l|}{ OP-20 FIXTURE CUTTING TIME } \\
\hline S No. & Operation & Tool & $\begin{array}{l}\text { Cycle } \\
\text { Time }\end{array}$ & RPM & Feed \\
\hline 1 & $\begin{array}{l}\text { Face } \\
\text { milling- } \\
\text { Rough }\end{array}$ & $\begin{array}{l}\varnothing 63 \\
\text { FMC }\end{array}$ & 8.08 & 1110 & 888 \\
\hline 2 & $\begin{array}{l}1 / 2 " \text { NPT } \\
\text { tapping }\end{array}$ & $\begin{array}{l}\varnothing 18.3 \\
\text { Drill }\end{array}$ & 0.96 & 1050 & 130 \\
\hline 3 & $\begin{array}{l}1 / 2 " N P \\
\text { T tap }\end{array}$ & 0.73 & 160 & 290 \\
\hline \multicolumn{7}{|l|}{ Total Time for OP-20 } & $\mathbf{9 . 7 7}$ & & \\
\hline
\end{tabular}

Cutting time for OP-20 $=9.77+10 \%$ cushion time

$$
=10.8 \mathrm{~min} \text {. }
$$

Non Cutting time for OP-10 includes

Loading time $=6 \mathrm{~min}$.

Work setting time $=10 \mathrm{~min}$

Unloading time $=5 \mathrm{~min}$.

Total non-cutting time for OP-20 $=21 \mathrm{~min}$.

Total Cycle time for OP-20 (cutting + Non-cutting) $=31.8 \mathrm{~min}$.

The total time of both OP-10 and OP-20 operation is $130.3 \mathrm{~min}$.

\subsection{Cutting force calculations}

For calculating the cutting forces, the operation in which max cutting forces will be induced was selected. The operations to be performed on the component are,

1. Face Milling of flanges (roughing and finishing),

2. Boring operation for $\varnothing 53 \mathrm{~mm}$ holes,

3. Drilling operation for $\varphi 25.4 \mathrm{~mm}$ holes.

Among the above the operations, major cutting forces will be induced during face milling (roughing) and then boring.

\subsubsection{For side face rough milling operation (B-90 or 270)}

Material of valve body is cast steel, cutting parameters and other details considered for cutting force calculations in this work are as follows:

Operation

Cutter

No of inserts

(D) : Ø 63 Face Mill cutter

Feed per tooth

(Z) : 4 inserts

Depth of cut

$\left(\mathrm{F}_{\mathrm{z})} \quad: 0.15 \mathrm{~mm}\right.$ to $\mathbf{0 . 2} \mathrm{mm}$

Feed per minute

(t) $\quad: 1.5-2 \mathrm{~mm}$

Cutting speed

$\left(\mathrm{F}_{\mathrm{m}}\right) \quad: \mathrm{mm}\left(\mathrm{F}_{\mathrm{z}} \times \mathrm{Z} \times \mathrm{n}\right)$

Spindle speed

$\left(\mathrm{V}_{\mathrm{c}}\right) \quad: 180-\mathbf{2 1 0} \mathrm{m} / \mathrm{sec}$

Width of cut

(n) $\quad: R P M\left(1000 \times V_{c} / \pi D\right)$

Cutting force

(b) $: 60 \mathrm{~mm}$

( $\left.\mathrm{F}_{\mathrm{c}}\right) \quad: \operatorname{Kgf}\left(\left(6120 \times \mathrm{P}_{\mathrm{c}}\right) / \mathrm{V}_{\mathrm{c}}\right)$ 


\section{Clamping force}

Cutting power

(F)

$$
\text { KN }\left(1.5 \times \mathrm{F}_{\mathrm{c}}\right)
$$

$\left(\mathrm{P}_{\mathrm{c}}\right): \mathrm{kW}\left(\left(\mathrm{t} \times \mathrm{b} \times \mathrm{F}_{\mathrm{m}} \times \mathrm{K}_{\mathrm{fs}}\right) /\left(60 \times 10^{5} \times \mathrm{\eta}\right)\right)$

Where, $\Pi$ is Efficiency of the machine.
RPM
(N) : Rev/min

Material removal rate (Q) $: \mathrm{mm}^{3} / \mathrm{sec}\left(\mathrm{b} \times \mathrm{t} \times \mathrm{F}_{\mathrm{m}} / 60\right)$

Specific cutting force $\left(\mathrm{K}_{\mathrm{fs}}\right): 260 \mathrm{~N} / \mathrm{mm}^{2}$

PS: SI Units considered, in brackets formulae used in calculations.

Considering maximum values of above preferred parameters, Spindle speed, feed per min, metal removal rate, clamping force, cutting force and cutting Power are calculated, formulae given above in brackets at the parameter [5].

$\mathrm{n}=1061.5$ RPM i.e., Taken as $1062 \mathrm{rpm}$

$\mathrm{F}_{\mathrm{m}}=850 \mathrm{~mm}$

$\mathrm{Q}=1700 \mathrm{~mm}^{3} / \mathrm{sec}$

$\mathrm{P}_{\mathrm{c}}=5.9 \mathrm{~kW}$

$\mathrm{F}_{\mathrm{c}}=171.94 \mathrm{Kgf}$ in Tangential direction.

$=1.686 \mathrm{kN}$

$\mathrm{F}=1.5 \times 1.686=2.54 \mathrm{kN}$

\subsection{Elements of Chain clamping fixture}

For Valve body machining as provide in the component operational geometrical requirements, two setups were selected (OP-10 \& OP-20) with two different fixtures with single part loadings.

\subsubsection{OP-10 Fixture concept details}

Fig. 8 is showing the fixture with component and without component. The component is located by V-block and orientated by two studs, which prevent the rotation of component in X-axis. It is clamped by the two set of chain. Maximum force applied by chain should be more than the clamping force. [6]

\subsubsection{OP-20 fixture concept details}

The location and orientation is done by cylindrical locating pin and diamond pin respectively. The clamping is done by top clamp with stud and washer as shown in figure 9 .

\section{Experimental details and results}

\subsection{Total Cycle time for OP-10}

Total cycle time $=64($ Cutting time $-\mathrm{CT})+6($ Setting time $-\mathrm{ST})=70 \mathrm{~min}$ (With pallet changer)
In case of single pallet machine, cycle time will include loading (L) and unloading (UL) time also. Then, the total cycle time is,

$$
\text { Cycle time }=70+20=90 \min \text {. }
$$

\subsection{Total Cycle time OP-20}

Total cycle time $=10(\mathrm{CT})+5(\mathrm{ST})=15 \mathrm{~min}$. (With Pallet changer)

$$
=15+10(\mathrm{~L} \text { and } \mathrm{UL})=25 \mathrm{~min} \text {. }
$$

Total cycle time $=115 \mathrm{~min}$ (for OP -10 and OP- 20)

The total cycle time for top clamping fixture is 145 $\min$ i.e $2.24 \mathrm{hr}$ per component. Production rate with this cycle time and 300 working days in a year having $16 \mathrm{hr}$ (two shifts in a day) of production in a day produces 1983 components per year

The total cycle time for chain clamping fixture is 115 min i.e $1.91 \mathrm{hr}$ per component. Production rate with this cycle time having 300 working days per year and production time of $16 \mathrm{hr}$ (two shifts in a day) yields 2513 components per year.

Therefore,

Increase in the Production rate of the component, $\mathrm{P}=$ $2513-1983=530$ Components per Year

\section{Conclusions}

The distribution of pressure induced by clamping is uniform and noise reduction while machining is reduced significantly. By using chain clamping over the component the cycle time was reduced by $20 \%$ (from 145 min to 115 min)for Gate valve body Component. The experimental results shown increase in Production rate by 530 numbers (26\%)components per year, from 1983 Numbers to 2513 Number per Year. Other parameters like vibrations and noise levels were observed decreasing due to increased fixture rigidity.

\section{References}

1. PradipBhaskarPatil, V. R Gambhire, "Structural Analysis of Gate Valve Body using F.E.A". International Journal of Engineering Research and Technology, 3, 6, June 2014.

2. Joe Cecil, Richard Mayer and Umesh Hari, "An integrated methodology of fixture design". Journal of intelligent manufacturing 7, 95-106, (1996).

3. Information on http://www.mmsonline.com .

4. Information on "Kennametal catalogue".

5. CMTI, "Machine Tool Design Handbook", TMH 1982.

6. Information on www.machinetoolsonline.com 